\title{
CARBON BALANCE IN ORGANIC CONILON COFFEE INTERCROPPED WITH TREE SPECIES AND BANANA
}

\author{
Diego Mathias Natal da Silva ${ }^{\odot}$, Letícia Célia Heitor ${ }^{3+}$, Aildosn de Oliveira Candido ${ }^{\oplus}$, Bárbara Santos

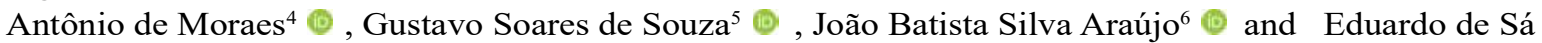 \\ Mendonça $^{7 *}$ (:)
}

\footnotetext{
${ }^{1}$ Received on 29.11.2019 accepted for publication on 21.05.2020.

${ }^{2}$ Instituto Federal do Sudeste de Minas Gerais, Ciência e Tecnologia do Sudeste de Minas Gerais, Manhuaçu, MG- Brasil. E-mail: $<$ diegoufvjm@yahoo.com.br>.

${ }^{3}$ Universidade Federal do Espírito Santo, Departamento de Agronomia, Alegre, ES- Brasil.

${ }^{4}$ Universidade Federal do Espírito Santo, Graduando em Agronomia, Alegre, ES- Brasil. E-mail: <aildsonoc@hotmail.com> and $<$ b.antoniodemoraes@gmail.com $>$.

${ }^{5}$ Instituo Federal do Espírito Santo, Itapina, ES- Brasil. E-mail: < gustavo.souza@ifes.edu.br>.

${ }^{6}$ Instituto Capixaba de Pesquisa Assistência Técnica e Extensão Rural, Venda Nova do Imigrante, ES- Brasil. E-mail: <joaoaraujovni@ gmail.com>.

${ }^{7}$ Universidade Federal do Espírito Santo, Departamento de Agronomia, Alegre, ES- Brasil. E-mail: <eduardo.mendonca@ufes.br>. *Corresponding author.

†' memorium.
}

\begin{abstract}
Over the last decade, conilon coffee (Coffea canephora) in consortium with wood trees has been established to improve environmental conditions. Little is known about how individual wood trees and banana affect soil quality when intercropped with conilon coffee. The objective of the present study was to evaluate the impacts of intercropping organic conilon coffee with different wood tree species and banana on $\mathrm{C}$ balance. Five cultivation systems including conilon coffee monoculture and intercropped with Inga edulis, Gliricidia sepium, BRS Japira banana (Musa sp.), or Bactris gasipaes were studied in a randomized complete block design, with four replicates at the south of Espírito Santo State, Brazil. A primary forest fragment adjacent to the experiment was also evaluated for comparison with the consortium. Samples of topsoil $(0$ to $10 \mathrm{~cm})$ were collected in 2016 to evaluate the total organic $\mathrm{C}$ and total $\mathrm{N}$. Soil temperature and moisture at 0 to $5 \mathrm{~cm}$ depth and the $\mathrm{CO}_{2}$ emission were measured monthly over one year. The species planted with the conilon coffee promoted a $5.52 \%$ decrease in the soil temperature and a $17 \%$ increase in the soil moisture content. They also promoted an increase in annual C balance, especially intercropped with Gliricidia and Inga (4.70 and $3.56 \mathrm{Mg}$ $\mathrm{ha}^{-1}$, respectively), with a substantial increase in the soil total organic $\mathrm{C}$ and total $\mathrm{N}$ in both systems.
\end{abstract}

Keywords: Coffea canephora; Agroforestry system; Soil organic matter.

\section{BALANÇO DE CARBONO NO SISTEMA DE CAFÉ CONILON ORGÂNICO CONSORCIADO COM ESPÉCIES ARBÓREAS E BANANA}

RESUMO - Na última década, o café conilon (Coffea canephora) em consórcio com árvores foi estabelecido para melhorar as condições ambientais. Pouco se sabe sobre como o cultivo de árvores e de banana afetam a qualidade do solo quando consorciados com café conilon. O objetivo do presente estudo foi avaliar os impactos do consórcio de café conilon orgânico com diferentes espécies arbóreas e banana no balanço de C. Cinco sistemas de cultivo, incluindo monocultura de café conilon e consorciados com Inga edulis, Gliricidia sepium, banana BRS Japira (Musa sp.) ou Bactris gasipaes foram estudados em delineamento de blocos ao acaso, com quatro repetições no sul do Espírito Santo, Brasil. Um fragmento de floresta primária adjacente ao experimento foi avaliado para comparação com o consórcio. Amostras superficiais de solo $(0$ a $10 \mathrm{~cm})$ foram coletadas em 2016 para avaliar o C orgânico total e o $N$ total. A temperatura e umidade do solo de 0 a $5 \mathrm{~cm}$ de profundidade e a emissão de $\mathrm{CO}_{2}$ foram medidas mensalmente ao longo de um ano. As espécies plantadas com o café conilon promoveram redução de 5,52\% na temperatura do solo e aumento de $17 \%$ no teor de umidade do solo. Também

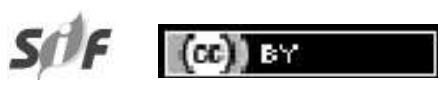

Revista Árvore 2020;44:e4421 http://dx.doi.org/10.1590/1806-908820200000021 
promoveu aumento no balanço anual de C, consorciado especialmente com Gliricidia e Inga (4,70 e 3,56 Mg $\mathrm{ha}^{-1}$, respectivamente), com aumento substancial no C orgânico total do solo e $\mathrm{N}$ total nos dois sistemas.

Palavras-Chave: Coffea canephora; Agroforestry system; Soil organic matter.

\section{INTRODUCTION}

Brazil is the world's largest coffee producer and exporter and the second in consumption (Kist et al., 2017). The agro-industrial coffee chain is one of the most important sectors of the Brazilian economy due to its significant participation in the export basket and in the generation of employment, which represents in the medium and long term, one of the main strategic products for the country (Lopes et al., 2019). The country's coffee production is based on two main species: arabica (Coffea arabica) and conilon/robusta (C. canephora).

Conilon is mainly produced and studied in the Espírito Santo state. This state is the second largest coffee producer in the country, responsible for up to $78 \%$ of the conilon production. Conilon coffee is the main source of income in $80 \%$ of rural properties in warm lands of Espírito Santo, with 283 thousand hectares in 63 municipalities, with 78 thousand producing families (Ferrão et al., 2019). According to CEDAGRO (2012), the conilon coffee plantations areas are highly degraded compared to the others agricultural areas in the state. The degradation of the conilon coffee areas is related to a series of factors, such as inadequate soil management practices, low vegetation cover, steep slopes, soil exposure to heave rain and solar radiation, which can promote losses in the stock of organic carbon and nutrients, reducing the soils productive capacity.

Tropical soil degradation can be monitored through its C content (Silva and Mendonça, 2007; Ghosh et al., 2012). Organic matter (OM) is considered a key component of any terrestrial ecosystem and is probably the most widely recognized indicator of the soil biological, physical and chemical properties, and is strongly associated with sustainable agroecosystems (Chen et al., 2009). Increasing or maintaining soil organic $C$ is critical to optimize soil functions and crop production, especially in tropical regions (Ghosh et al., 2012).

Carbon sink in the soil is associated to geographic location, environmental factors, and management practices, among others (Jose, 2009). Soil management can influence organic matter decomposition, contributing to its degradation and can increase the atmospheric $\mathrm{CO}_{2}$
concentration(Silva and Mendonça, 2007). Carbon losses may be mainly reduced by minimizing soil disturbance, with increasing soil cover, adopting agroecological or organic systems (Silva and Mendonça, 2007). The agroecological and organic systems have focus on soil health and productivity, associated to environmental preservation, agrobiodiversity, biological cycles and human quality of life (Souza, 2015). It is estimated that $89 \%$ of the greenhouse gas mitigation potential of agriculture depends on $\mathrm{C}$ sequestration (Smith et al., 2008). In addition, increasing the soil organic $C$ is an important strategy for attenuating climate change effect regarding to $\mathrm{CO}_{2}$ emissions to the atmosphere from agricultural land (Thomazini et al., 2015).

The use of agroforestry systems or intercropped trees with conilon coffee seems to be an alternative to reduce soil degradation due to higher levels of organic $\mathrm{C}$ in the soil of these systems when compared to coffee monocultures (Paudel et al., 2011). An abundant soil plant cover controls soil $\mathrm{CO}_{2}$ emissions of the soil, because it regulates the microclimate and soil physical, biological and chemical conditions of the soil (Gomes et al., 2016). The agroforestry systems can also contribute to attenuate the climatic stresses (drought, high temperature, and insolation). These stresses lead to the decline of the conilon coffee productivity mainly in the state of Espírito Santo (CONAB, 2017).

Agroforestry systems allow the diversification of the allocation of $\mathrm{C}$ production into plant biomass and increase the input of organic matter residues to the soil (Ehrenbergerová et al., 2015). If implemented globally, agroforestry systems could remove significant amounts of $\mathrm{C}$ (1.1-2.2 Pg C in fifty years) from the atmosphere (Abbas et al., 2017). Furthermore, when intercropping with leguminous trees, the residues can also contribute to increase $\mathrm{N}$ pool (nutrient with high demand for coffee crop) into the soil due to the biological fixation (Paulino et al., 2009). Agroforestry systems increase the efficiency of the system resources use (Eichhorn et al., 2006), providing goods (food, wood products and forage) and services (soil conservation, improvement of water and air quality, biodiversity and scenic beauty) (Chen et al., 2020). 
Coffee cultivation in agroforestry systems is common in Central and South America but is underrepresented in Brazil (Edenhofer et al., 2014), where coffee plantations are predominantly a monocultures. Arabica coffee has been studied in agroforestry systems, exhibiting benefits to edaphic and microclimatic conditions (Gomes et al., 2016).

In spite of the advances in research on tropical soils cultivated with arabica coffee in agroforestry systems, little information is available for organic conilon coffee. Knowledge is also lacking on the role of the individual plants intercropped with coffee on $\mathrm{C}$ balance. The aim of this study was to evaluate the effect of conilon coffee plantations, mixed with tree species and banana, on $\mathrm{C}$ balance.

\section{MATERIAL AND METHODS}

\subsection{Experimental area}

The experiment was set up in January 2013 at the Experimental Bananal do Norte Farm, which belongs to the INCAPER (Instituto Capixaba de Pesquisa, Assistência Técnica e Extensão Rural), at Cachoeiro de Itapemirim, Espirito Santo, Southeastern Brazil (2045'15's; 41 $\left.{ }^{\circ} 17^{\prime} 05^{\prime \prime} \mathrm{W} ; 146 \mathrm{~m}\right)$. Data collection was performed monthly from March 2016 to February 2017.

The climate is Köppen 'Cwa', with rainy summer and dry winter, average annual precipitation of 1,200 $\mathrm{mm}$, lowest temperatures in the coldest months range from 11.8 to $18^{\circ} \mathrm{C}$ and highest temperatures in the hottest months is from 30.7 to $34^{\circ} \mathrm{C}$ (Figure 1)

The soil in the experimental area is an eutrophic Fluvic Neosol, with clayey texture (Embrapa, 2014). Soil samples of surface soil (0-10 cm depth) were collected in 2015 for physical and chemical characterization, being: $\mathrm{pH}$ in water, 6.60; available $\mathrm{P}, 62.87 \mathrm{mg} \mathrm{dm}^{-3}$ (Mehlich 1); available K, $209.2 \mathrm{mg} \mathrm{dm}^{-3}$; exchangeable $\mathrm{Ca}, 3.87 \mathrm{cmol}_{\mathrm{c}} \mathrm{dm}^{-3}$; exchangeable $\mathrm{Mg}, 0.88 \mathrm{cmol}_{\mathrm{c}}$ $\mathrm{dm}^{-3}$; exchangeable $\mathrm{Al}, 0.0 \mathrm{cmol}_{\mathrm{c}} \mathrm{dm}^{-3}$; sum of bases, $5.36 \mathrm{cmol}_{\mathrm{c}} \mathrm{dm}^{-3}$; effective CEC, $5.36 \mathrm{cmol}_{\mathrm{c}} \mathrm{dm}^{-3}$; base, $69.59 \%$; and $45 \%$ sand, $10 \%$ silt and $45 \%$ clay.

\subsection{Experimental design}

The experiment was set in a randomized complete block design with four replicates. Treatments involved five organic cropping systems of conilon coffee: one in monoculture and four others mixed with different tree species and banana: Inga edulis, Gliricidia sepium, BRS Japira banana (Musa sp.) and Bactris gasipaes. A primary fragment of native Atlantic Forest adjacent to the experiment was also evaluated as a reference with the conilon coffee treatments.

Each experimental plot consisted of five rows with 25 coffee plants each $\left(375 \mathrm{~m}^{2}\right)$ (Figure 2$)$. Measurements of soil temperature, moisture and $\mathrm{CO}_{2}$ emission and soil samples were taken between two coffee plants, $10 \mathrm{~cm}$ from the central row in each plot. Four $200-\mathrm{m}^{2}$ areas were set in the native forest fragment, which was under selective logging over the last 20 years, to make the measurements and take soil samples.

\subsection{Planting and culture methods}

Coffee seedlings (variety 'Emcaper 8151 Robusta Tropical') were planted in a $3.0 \times 1.0 \mathrm{~m}$ spacing, ie, 3,333 plants ha-1. Other tree species and banana were established within coffee rows in a $3.0 \times 6.0 \mathrm{~m}$ spacing (1/6 of the planting pits received one of the intercropped species). Planting densities was 2.777 conilon plants ha $^{-1}$ intercropped coffee and 556 plants $\mathrm{ha}^{-1}$ for the intercropped species

Irrigation was supplied only in the first 4 months. At the beginning, fertilization consisted of $300 \mathrm{~g}$ reactive natural phosphate, $200 \mathrm{~g}$ limestone, and $2 \mathrm{~kg}$ chicken manure per pit, as recommended by Prezotti

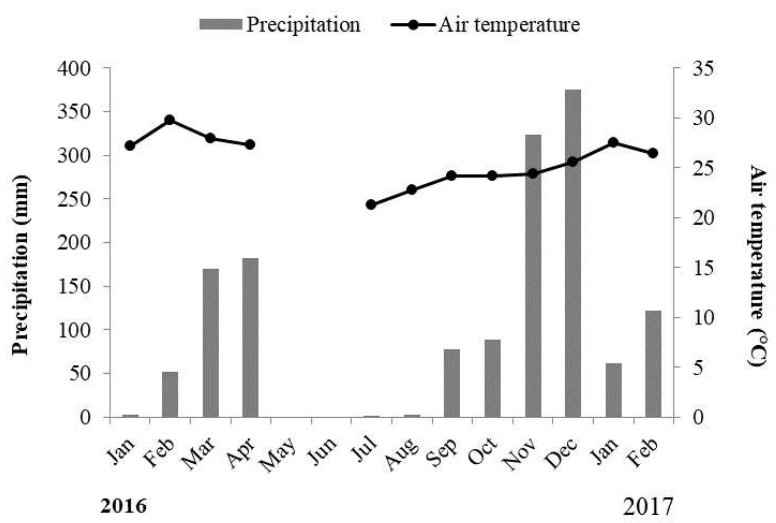

Figure 1 - Precipitation and average air temperature observed during the experimental period, January 2016-February 2017. Source: INMET automatic weather station

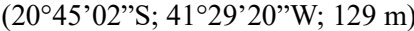

Figura 1 - Precipitação e temperatura média do ar observadas durante o periodo experimental, janeiro de 2016 a fevereiro de 2017. Fonte: Estação meteorológica automática do INMET (20 $45^{\prime} 02$ 's; $41^{\circ} 29^{\prime} 20^{\prime \prime} \mathrm{W}$; $129 \mathrm{~m})$.

\author{
Revista Árvore 2020;44:e4421
}



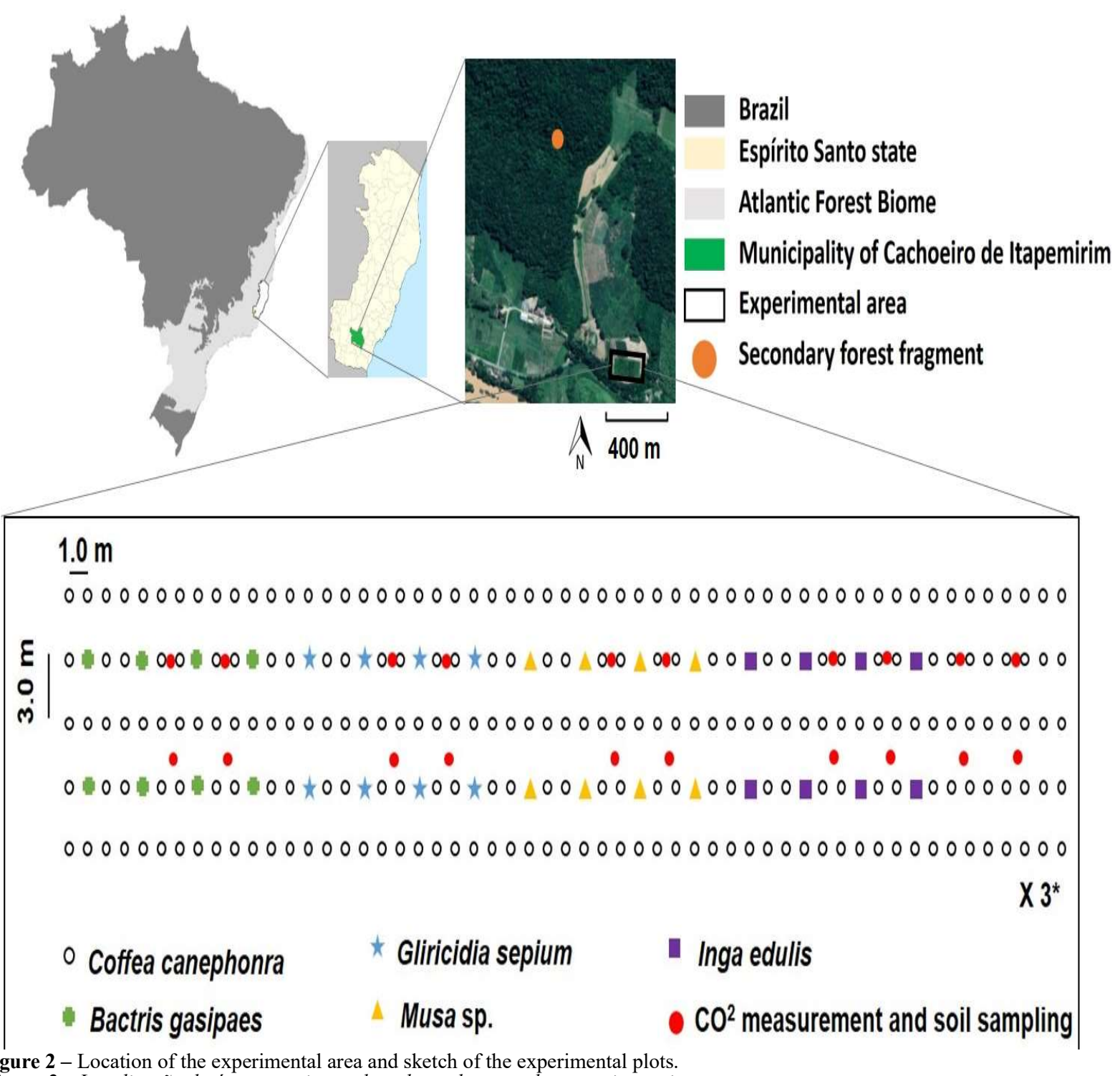

Figure 2 - Location of the experimental area and sketch of the experimental plots.

Figura 2 - Localização da área experimental e esboço das parcelas experimentais.

et al. (2007), providing 93, 137 and $47 \mathrm{~kg} \mathrm{ha}^{-1}$ of $\mathrm{N}, \mathrm{P}$ and $\mathrm{K}$, respectively. Cover fertilization was carried out twice a year (March and August), totalling 2.50 and $5.67 \mathrm{Mg} \mathrm{ha}^{-1}$ of chicken manure dry mass (1.70, 2.09 and $1.76 \%$ of $\mathrm{N}, \mathrm{P}$ and $\mathrm{K}$, respectively) and organic compost dry mass $(1.30,0.73$ and $0.92 \%$ of N, P and $\mathrm{K}$, respectively), supplying 103, 99 and $46 \mathrm{~kg} \mathrm{ha}^{-1}$ of N, P and $\mathrm{K}$, respectively. Removal of spontaneous plants was carried out three times per year by mowing between the rows and weeding within the planting rows. These are standard practices in the region.
Annually, the horizontal branches of the coffee tree were cut and eliminated, keeping four vertical branches per plant as recommended by Ferrão et al. (2008), which reached $70 \%$ of the production. In 2016, the amount of waste generated by these practices was determined by randomly collecting the biomass of five plants per experimental unit. After determining the fresh mass, a sample of 300 grams of each experimental unit was oven dried with forced air ventilation at $65^{\circ} \mathrm{C}$ until reaching constant mass. Subsequently, the production of dry mass per area was estimated.

Revista Árvore 2020;44:e4421 


\subsection{Intercropped trees and banana}

The Inga and Gliricidia were intercropped with conilon coffee in order to provide non-market goods and services (soil cover, microclimate improvement, shading, $\mathrm{C}$ and $\mathrm{N}$ input to the soil, among others). The Musa and Bactris, besides providing some non-market goods and services (soil cover, shading, C supply, among others), are alternative crops, providing food or goods (banana and heart-of-palm).

The Gliricidia and Inga trees were first pruned for shape in March 2015 to raise the crown above 4 $\mathrm{m}$ height. Pruning was conducted in the months of March and August every year. Musa was kept with four pseudo-stems per mat (the parent tree and three 'suckers'). Bactris was shaped without thinning the offshoots. Musa and Bactris stalks were first cut for fruit and heart-of-palm, respectively, in 2014 and every subsequent 2 to 3 months, depending on to have fruit and palm. Residues from the prunings and cuts of the intercropped trees were deposited on the soil floor along the planting line.

In 2016, the amount of residues from pruning and cutting of the intercropped plants was determined by randomly collecting the biomass of four plants per experimental unit. After determining the fresh mass of each plant, a sample of 300 grams of each experimental unit was oven dried with forced air ventilation at $65^{\circ} \mathrm{C}$ until reaching constant mass.

\section{5. $\mathrm{CO}_{2}$ emissions, Q10, soil temperature and moisture content}

The $\mathrm{CO}_{2}$ emissions, soil temperature and moisture content were measured monthly between March 2016 and February 2017. The $\mathrm{CO}_{2}$ emissions were measured with a LI-8100 portable analyzer (Li-Cor, USA) coupled to a $10 \mathrm{~cm}$ survey chamber (LI-8100-102) placed in PVC collars at a $5 \mathrm{~cm}$ depth, 40 minutes before measurements were taken. Three measurements were taken in each experimental plot. For each $\mathrm{CO}_{2}$ measurement, soil temperature and moisture values were also taken at the 5 cm depth with a soil moisture sensor (Decagon Devices, USA).

To compare sensitivity to soil temperatures across the different systems, the proportional variation in the soil $\mathrm{CO}_{2}$ emissions was calculated when the soil temperature increased by $10^{\circ} \mathrm{C}(\mathrm{Q} 10)$, based on the ratio between the soil temperature at the $5-\mathrm{cm}$ depth and the amount of soil
$\mathrm{CO}_{2}$ emissions. An exponential regression was applied to obtain the relation between the $\mathrm{CO}_{2}$ emissions and soil temperature (Eq. (1)):

$\mathrm{ECO} 2=\alpha \times \mathrm{e}^{(\beta 1 \times \mathrm{T})}(1)$, where $\mathrm{ECO}_{2}$ is the quantity of soil $\mathrm{CO}_{2}$ emissions ( $\mu \mathrm{mol} \mathrm{m} \mathrm{m}^{-2} \mathrm{~s}^{-1}$ ), $\mathrm{T}$ is the soil temperature $\left({ }^{\circ} \mathrm{C}\right), \alpha$ is the intercepted $\mathrm{CO}_{2}$ emissions at $\mathrm{T}=0$, and $\beta 1$ is the regression coefficient, obtained from the natural logarithm of the $\mathrm{CO}_{2}$ emission amount and the soil temperature at a $5 \mathrm{~cm}$ depth. The Q10 values were thus obtained according to Eq. (2) (Gomes et al., 2016): $\mathrm{Q} 10=\mathrm{e}^{10 \times \beta 1}(2)$

\subsection{Annual net carbon balance}

Annual net $\mathrm{C}$ balance was estimated as the difference between the means of the $\mathrm{CO}_{2}$ emission and $\mathrm{C}$ input during the experimental period. Annual emissions were calculated based on the average measurements. Reported $\mathrm{C}$ input refers to the $\mathrm{C}$ from the coffee and intercropped tree plant residues and to the $\mathrm{C}$ from the chicken manure and organic compost applied as fertilizer. Residues from spontaneous plants were disregarded. The equivalence between $\mathrm{C}$ and $\mathrm{CO}_{2}$ was based on element molecular weights, in which one mole of $\mathrm{CO}_{2}$ contains $12,011 \mathrm{~g}$ of $\mathrm{C}$.

Coffee and intercropped plant biomass, along with chicken manure and organic compost used as fertilizers, were collected (300 grams of each material) and dried in a continuous air circulation oven $\left(65^{\circ} \mathrm{C}\right)$ until a constant mass was reached. The total $\mathrm{C}$ of these materials was determined by loss on ignition at $430{ }^{\circ} \mathrm{C}$ for $24 \mathrm{~h}$ in a muffle furnace (Kiehl, 1985) and showed the following C contents: $470 \mathrm{~g} \mathrm{~kg}^{-1}$ for Inga and Gliricidia plant residue, $480 \mathrm{~g} \mathrm{~kg}^{-1}$ for Musa and Bactris residue, 450 $\mathrm{g} \mathrm{kg}^{-1}$ for coffee plant residue and organic compost, and $140 \mathrm{~g} \mathrm{~kg}^{-1}$ for chicken manure.

\subsection{Soil organic matter}

Samples of top soil $(0-10 \mathrm{~cm})$, below the litter, were collected in March, June, September and December 2016. In each experimental plot, three soil samples were collected, forming a composite soil sample to determine total organic carbon (TOC) and total nitrogen $(\mathrm{TN})$.

Soil TOC was determined through wet oxidation with $\mathrm{K}_{2} \mathrm{Cr}_{2} \mathrm{O}_{7}$ (Yeomans and Bremner, 1988), and TN by Kjeldahl distillation (Bremner and Mulvaney, 1982; Tedesco et al., 1995).

\section{Revista Árvore 2020;44:e4421}




\subsection{Data analysis}

The annual average of the data were submitted to analysis of variance (ANOVA) through an F test, and the mean values were compared by Skott-Knott $(p<0.10)$, $10 \%$ level of significance due to high soil variability. Statistical analyses were performed using the software SISVAR (Ferreira, 2014).

\section{RESULTS}

\subsection{Biomass production and carbon input in the soil}

The pruning performed in the Gliricidia contributed to the greatest input of dry mass $(12,62$ $\mathrm{Mg} \mathrm{ha}{ }^{-1}$ ) and $\mathrm{C}\left(5.93 \mathrm{Mg} \mathrm{ha}^{-1}\right)$ in the soil, followed by Inga (9.59 and 4.51 $\mathrm{Mg} \mathrm{ha}^{-1}$, respectively). Musa and Bactris at the time of harvest promoted similar inputs of dry mass and $\mathrm{C}$ in the soil (mean of 2.40 and 1.16 $\mathrm{Mg} \mathrm{ha}^{-1}$, respectively).

In 2016, the amount of residues from the coffee tree (branches and leaves) averaged 3.30 $\mathrm{Mg} \mathrm{ha}^{-1}$ of dry mass in all cropping systems.

\subsection{Soil temperature and moisture content, and $\mathrm{CO}_{2}$ emission}

The treatment $\mathrm{CM}$ presented the highest soil temperature (mean of $30.07 \mathrm{oC}$ ). The lowest annual mean of soil moisture also occurred in the CM (20\%), which did not differ from coffee intercropped with Inga (CI), Musa (CB) and forest (mean of 21.5\%). The highest values occurred in coffee intercropped with Gliricidia (CG) (mean of 25\%) and Bactris (CP) (mean of 26\%) (Figure 4B).

The highest annual mean soil $\mathrm{CO}_{2}$ emissions occurred in the $\mathrm{CI}, \mathrm{CG}$ and $\mathrm{CB}$, which did not differ among them (mean of $3.10 \mu \mathrm{mol} \mathrm{m} \mathrm{m}^{-2}$ ), while the others systems had lower annual averages (mean of $2.58 \mu \mathrm{mol}$ $\mathrm{m}^{-2} \mathrm{~s}^{-1}$ )(Figure 4C). The highest Q10 value was found in the forest (2.49), followed by CP (2.0), and the lowest value in the CI (1.16). The other systems presented close values of Q10 (mean of 1.51) (Figure 4D).

\subsection{Annual net carbon balance and total soil carbon and nitrogen content}

In the estimation of annual net $\mathrm{C}$ balance, it was not considered the root systems and coffee production (Figure 5). The high $\mathrm{C}$ input from pruning by the different intercropped plants contributed to the positive annual $\mathrm{C}$ balance (Figure 5a). The differences between the input and the losses were 3.56, 4.70, 0.57 and $0.84 \mathrm{Mg} \mathrm{ha}^{-1}$ for CI, CG, CB and CP, respectively. The annual net balance was negative in CM (-0.19 $\mathrm{Mg} \mathrm{ha}^{-1}$ ), despite the contributions of $3.30 \mathrm{Mg} \mathrm{ha}^{-1}$ dry mass from coffee tree residues and 2.50 and $5.67 \mathrm{Mg}$ ha $^{-1}$ dry mass from the chicken manure and organic compost, respectively.

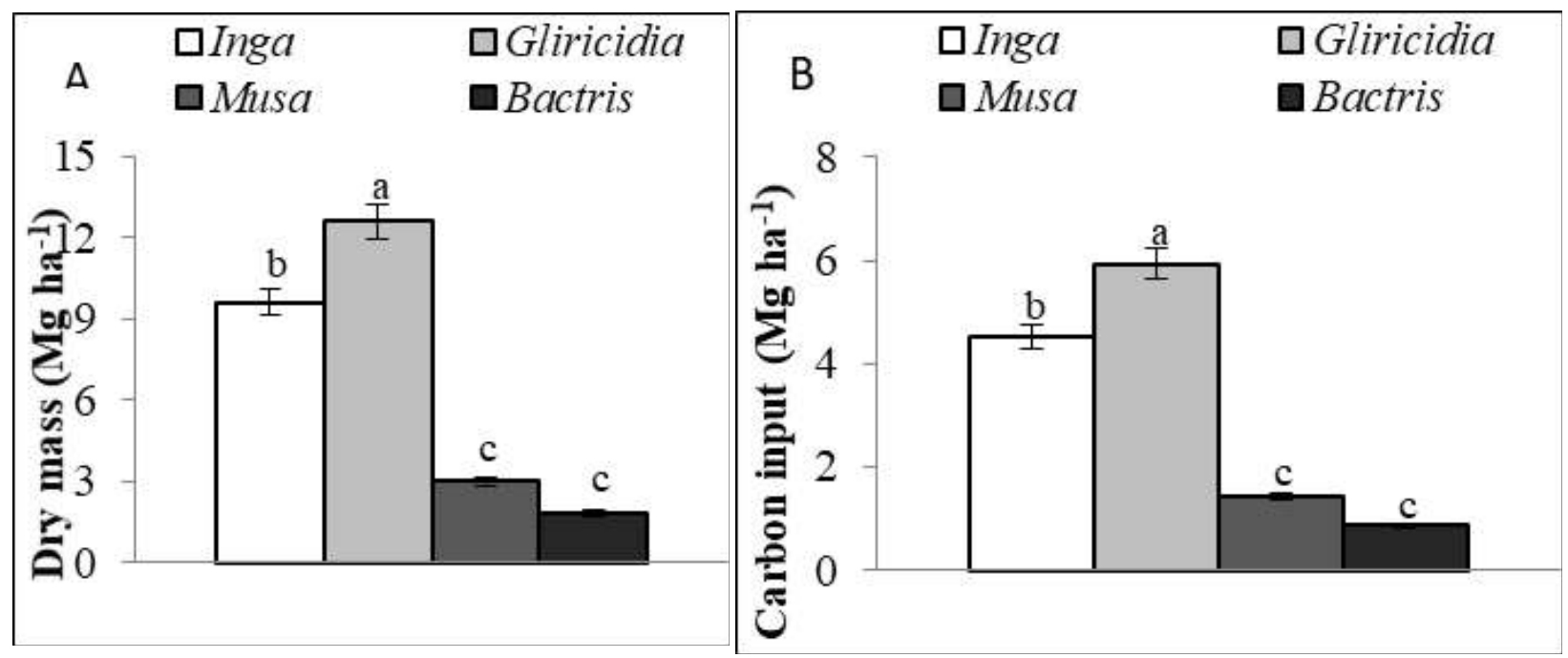

Figure 3 - Production of dry mass (a) and soil carbon input (b) through the residues of the trees intercropped with conilon coffee in the year 2016. Mean values followed by the same letter did not differ by Scott-Knott test $(\mathrm{p}<0.10)$.

Figura 3 - Produção de massa seca (a) e aporte de carbono do solo (b) através dos resíduos das árvores consorciadas com café conilon no ano de 2016. Os valores médios seguidos pela mesma letra não diferiram pelo teste de Scott-Knott $(p<0,10)$.

Revista Árvore 2020;44:e4421 

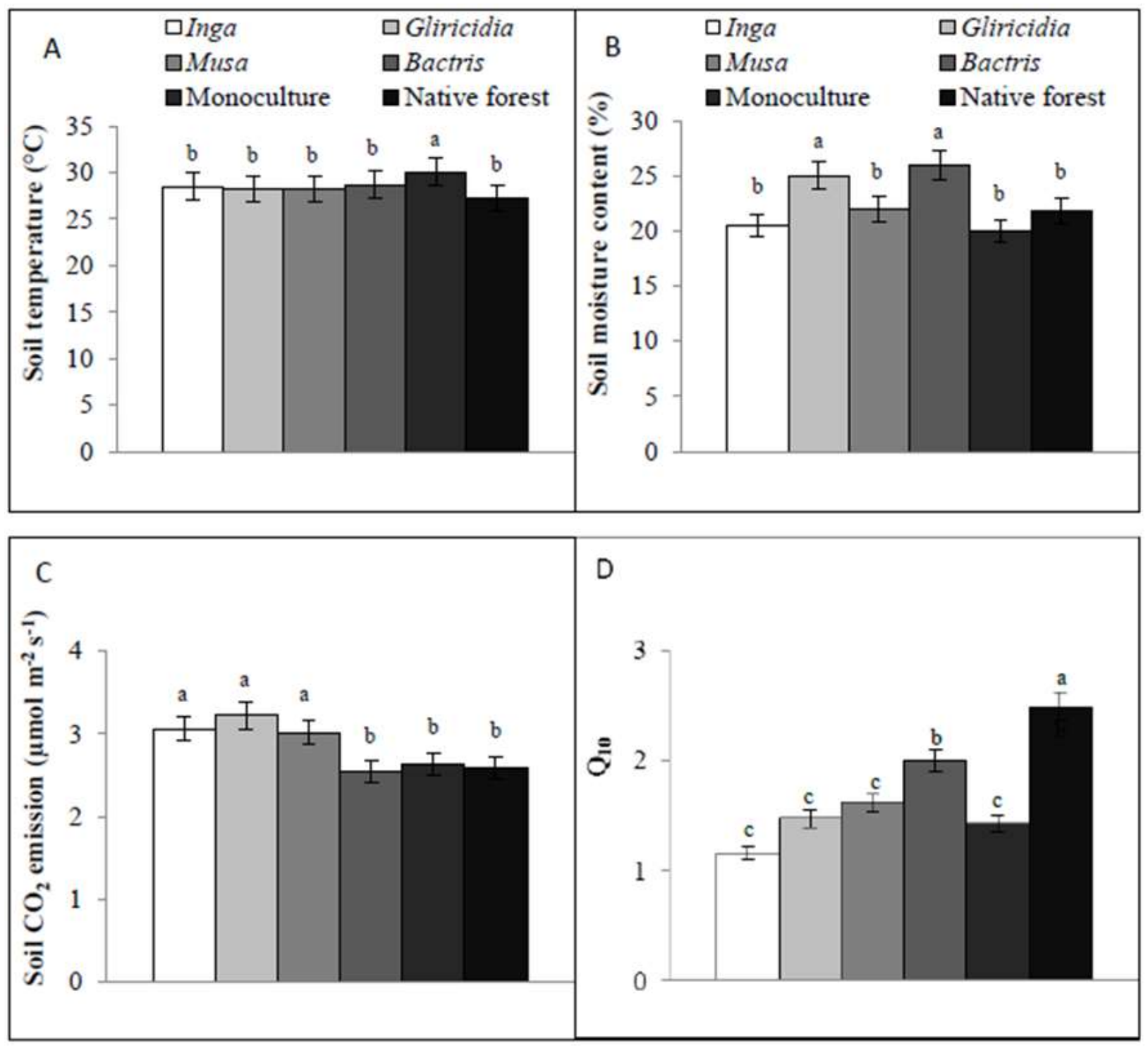

Figure 4 - Annual average of soil temperature (a), moisture (b), $\mathrm{CO}_{2}$ emissions (c) and Q10 (d) in conilon coffee organic plots intercropped with tree species. Mean values followed by the same letter did not differ by Scott-Knott test $(\mathrm{p}<0.10)$.

Figura 4 - Média anual da temperatura do solo (a), umidade (b), emissões de $\mathrm{CO}$ (c) e Q10 (d) em parcelas café conilon orgânico consorciado com espécies arbóreas. Os valores médios seguidos pela mesma letra não diferiram pelo teste de Scott-Knott $(p<0,10)$.

The soil under forest presented the highest TOC and $\mathrm{TN}$ values, followed by $\mathrm{CG}$ and $\mathrm{CI}$. The lowest TN values were obtained in $\mathrm{CM}$ and $\mathrm{CB}$ (Figure 5B, Figure 5C).

\section{DISCUSSION}

\subsection{Soil temperature, moisture content, and $\mathrm{CO}_{2}$ emission}

The higher inputs of dry mass and $\mathrm{C}$ in the soil from the pruning residues of Gliricidia and Inga provide soil cover, microclimate, shading, $\mathrm{C}$ and $\mathrm{N}$ in the soil, wood, among others. Intercropping plants in the conilon coffee culture resulted, on average, in a $5.52 \%$ decrease in the soil temperature and a $17 \%$ increase in the soil moisture content compared to $\mathrm{CM}$, due to the reduction of the amount of solar radiation reaching the soil (Gomes et al., 2016). Under climate change scenarios (Stocker et al., 2013), the microclimate regulation provided by the canopies may become crucial for the production of 

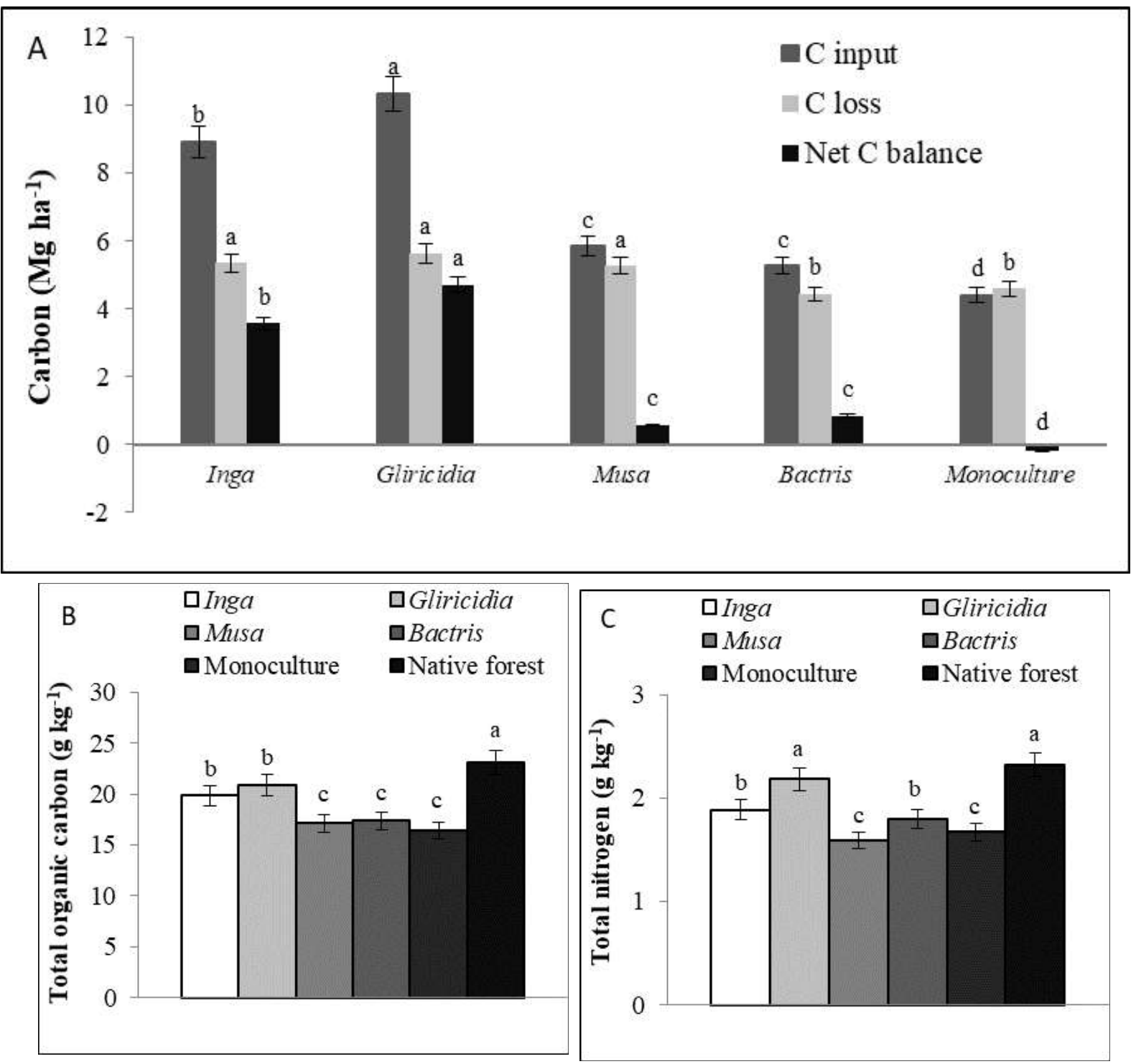

Figure 5 - Net $\mathrm{C}$ balance between inputs (organic fertilization and intercropped species residues) and losses $\left(\mathrm{CO}_{2}\right.$ emissions) of carbon (a), and average annual total organic $\mathrm{C}(\mathrm{b})$ and $\mathrm{N}$ (c) contents of soil in organic conilon coffee culture intercropped with different tree species. Mean values followed by the same letter did not differ by Scott-Knott test $(\mathrm{p}<0.10)$.

Figura 5 - Balanço líquido de C entre aportes (fertilização orgânica e resíduos de espécies consorciadas) e perdas (emissões de CO) de carbono (a) e o teor médio anual total de $C(b)$ e $N$ (c) do solo na cultura do café conilon orgânico consorciado com diferentes espécies de árvores. Os valores médios seguidos pela mesma letra não diferiram pelo teste de Scott-Knott $(p<0,10)$.

conilon coffee, which requires mild air temperatures $(22$ and $26^{\circ} \mathrm{C}$ ) for optimal growth (Ferrão et. al, 2012).

The soil moisture conditions in agroecosystems are also an important issue. The canopy helps to maintain high soil moisture (Gomes et al., 2016; Liu et al., 2013) as the soil cover favours reduction of soil evaporation. Coffee production is extremely sensitive to soil water availability, as the adequate soil water supply is necessary for the development of coffee fruits (Cannell, 1983). The water availability in the region concentrates in January and February (rainy season), however, short dry periods may lead malformation of coffee beans. Thus, intercropping tree plants and banana may provide better conditions to retain (Liu et al., 2013) and improve the coffee fruit size (Vaast et al., 2006). Bigger size

Revista Árvore 2020;44:e4421 
coffee fruits has positive economic impact once the production achieves high value in the market (Mehta and Chavas, 2008).

Annual $\mathrm{CO}_{2}$ emissions are great in $\mathrm{CI}, \mathrm{CG}$ and $\mathrm{CB}$, in response to the greater input of organic matter and $\mathrm{C}$ from pruning of Inga and Gliricidia, and from Musa harvesting. Higher soil moisture content in CP might decrease soil porosity and consequently the $\mathrm{CO}_{2}$ diffusivity (Daly et al., 2008) and $\mathrm{CO}_{2}$ respiration (Hanson et al., 2000). Higher soil temperatures in CM may have blocked the microorganism respiration (Jiang et al., 2015). The lowest annual $\mathrm{CO}_{2}$ emission from the forest system, as compared to agroecosystems, may be due to the low soil disturbance (Gomes et al., 2016).

Different species in consortium with coffee plantation may improve the environmental condition, at least at the soil surface, due to improving biological activity (Katayama et al., 2009). The trees and banana plants used for intercropping with the conilon plantation contributes to the organic matter pool, nutrient cycle and stimulates soil respiration and, therefore, the $\mathrm{CO}_{2}$ emissions.

The Q10 has been used for the analyses of soil $\mathrm{CO}_{2}$ emissions and to determine soil temperature sensitivity (Gomes et al., 2016; Thomazini et al., 2015), as the Q10 reflects the ecosystem climatic variation (Raich and Schlesinger, 1992). The highest Q10 values were obtained in the native forest, and the lowest for the CI system. These data indicate lower sensitivity of CI system to global warming compared to the other systems. May be the low decomposition rate of Inga residue, increasing the amount of residue on the soil and the period of soil cover (Duarte et al., 2013), may turn the soil to be more resilient to climate changes.

Despite the lower input of dry mass and $\mathrm{C}$ in the soil by the Musa and Bactris cutting residues, both species are alternative crops and were intercropped with conilon coffee with the main objective of providing food or merchandise (banana and palm heart).

\subsection{Annual net carbon balance and total soil carbon and nitrogen content}

The annual net $\mathrm{C}$ balance calculated represents 13.05, 17.23, 2.09 and 3.08 $\mathrm{Mg} \mathrm{ha}^{-1} \mathrm{CO}_{2}$ equivalents for $\mathrm{CI}, \mathrm{CG}, \mathrm{CB}$ and $\mathrm{CP}$, respectively. The coffee monoculture presented a negative $\mathrm{CO}_{2}$, equivalent $\left(-0.70 \mathrm{Mg} \mathrm{ha}^{-1}\right)$, despite the input of dry mass from coffee tree residues and organic manure. Jia et al. (2012) reported that C inputs in organic crop production systems consisted mainly of organic manure and crop residues, and they, usually, represent $23-73 \%$ and $11-16 \%$, respectively, of the increase in total soil $\mathrm{C}$. Carbon losses due to $\mathrm{CO}_{2}$ emissions were higher in the $\mathrm{CI}, \mathrm{CG}$ and $\mathrm{CB}$ systems. However, soil $\mathrm{C}$ inputs through plant from the pruning and cutting residues of intercropped tree species and banana contribute to a positive annual balance, especially in Inga and Gliricidia. In CI and CG, the crop residues contributed to about $50 \%$ of the $\mathrm{C}$ input.

The higher annual average values for the TOC and TN contents in CG and CI are associated with the larger input of organic residues from tree pruning (Abbas et al., 2017). Furthermore, Inga and Gliricidia are leguminous trees (Fabaceae), that accumulate significant amount of $\mathrm{N}$ due to the biological fixation (Romero-Alvarado et al., 2002), and build up soil organic matter (Silva and Mendonça, 2007). According to Paulino et al. (2009), Gliricidia may show up to $80 \%$ of the $\mathrm{N}$ due to the biological fixation. Nitrogen is one of the most important nutrients for several plants for both the vegetative and reproductive growth (Cantarella et al., 2007). Thus, intercropping conilon coffee with leguminous trees is an alternative to increase soil $\mathrm{N}$ content, especially in organic production, decreasing $\mathrm{N}$ fertilizers.

\section{CONCLUSION}

Organic cultivation of conilon coffee intercropped with trees and banana, especially with Gliricidia and Inga, may increase $\mathrm{C}$ sequestration, increasing the levels of soil total organic $\mathrm{C}$ and $\mathrm{N}$, and improve $\mathrm{C}$ balance. It results in lower soil temperature and increased soil moisture.

The use of tree species, especially leguminous trees, intercropped with conilon coffee in organic or conventional production systems should be encouraged to improve the sustainability of the agricultural systems in the domain of Atlantic Forest biome.

\section{ACKOWLEDGMENT}

To CAPES (Coordination for Improvement of Higher Education), FAPES (Research Support Foundation of Espírito Santo) and $\mathrm{CNPq}$ (National Council for Scientific and Technological Development) for their financial support and granting scholarships and research.

Revista Árvore 2020;44:e4421 


\section{REFERENCES}

Abbas F, Hammad HM, Fahad S, Cerdà A, Rizwan M, Farhad W, et al. Agroforestry: a sustainable environmental practice for carbon sequestration under the climate change scenarios - a review. Environmental Science and Pollution Research. 2017;24(12):11177-191. doi: doi.org/10.1007/ s11356-017-8687-0

Bremner JM, Mulvaney CS. Total nitrogen. In: Page AL (ed.) Methods of soil analysis. American Society of Agronomy. Madison; 1982. p. 595-624. ISBN 9780891189770

Cannell MGR. Coffee. Biologist. 1983;30:257-63.

Cantarella H. Nitrogênio. In: Novais RF, Alvarez VVH, Barros NF, Fontes RL, Cantarutti RB, Neves JCL, editores. Fertilidade do solo. Viçosa, MG: Sociedade Brasileira de Ciência do Solo; 2007. p. 375-470. ISBN 9788586504082

Centro de Desenvolvimento do Agronegócio CEDAGRO. Documento Resumo. Levantamento de áreas agrícolas degradadas no Estado do Espírito Santo. Vitória, ES: CEDAGRO; 2012. 18 p.

Chen H, Hou R, Gong Y, Li H, Fan M, Kuzyakov Y. Effects of 11 years of conservation tillage on soil organic matter fractions in wheat monoculture in Loess Plateau of China. Soil Tillage Research. 2009;106(1):85-94. doi: doi.org/10.1016/j. still.2009.09.009

Chen X, Chen HYH, Chen C, Ma Z, Searle EB, $\mathrm{Yu} Z$, et al. Effects of plant diversity on soil carbon in diverse ecosystems: a global meta-analysis. Biological Reviews. 2020;95(1):167-83. doi: https:// doi.org/10.1111/brv.12554

Companhia Nacional de Abastecimento - CONAB. Acompanhamento da safra brasileira: café, v. 4 Safra 2017, n. 1 - Primeiro levantamento, Brasília, 2017; 98 p.

Daly E, Oishi AC, Porporato A, Katul GG. A stochastic model for daily subsurface $\mathrm{CO} 2$ concentration and related soil respiration. Advances in Water Resources. 2008;31(7): 987-94. doi: https:// doi.org/10.1016/j.advwatres.2008.04.001

Duarte EMG, Cardoso IM, Stijnen T, Mendonça
MAFC, Coelho MS, Cantarutti RB, et al.

Decomposition and nutrient release in leaves of Atlantic Rainforest tree species used in agroforestry systems. Agroforestry System. 2013;87:835-47. doi: https://doi.org/10.1007/s10457-013-9600-6

Edenhofer O, Pichs-Madruga R, Sokona Y. IPCC, 2014: climate change 2014: mitigation of climate change. In: Contribution of Working Group III to the Fifth Assessment Report of the Intergovernmental Panel on Climate Change. Edenhofer OR, PichsMadruga Y, Sokona E, Farahani S, Kadner K, Seyboth A, et al, editors. Cambridge, United Kingdom and New York, USA: Cambridge University Press; 2014.

Ehrenbergerová L, Cienciala E, Kučera A, Guy L, Habrová H. Carbon stock in agroforestry coffee plantations with different shade trees in Villa Rica, Peru. Agroforestry System. 2015;90:433-45. doi: https://doi.org/10.1007/s10457-015-9865-z

Eichhorn MP, Paris P, Herzog F, Incoll LD, Liagre F, Mantzanas K, et al. Silvoarable systems in Europepast, present and future prospects. Agroforestry System. 2006;67:29-50. doi: doi.org/10.1007/ s10457-005-1111-7

Embrapa. Sistema brasileiro de classificação de solos, 4th ed. Centro Nacional de Pesquisa de Solos. Rio de Janeiro, RJ: Embrapa; 2014. 377 p.

Ferrão RG, Fonseca AFA, Ferrão MAG, De Muner LH, Verdin Filho AC, Volpi OS, et al. Café conilon: técnicas de produção com variedades melhoradas. $4^{\mathrm{a}}$ ed. Vitória, ES: Incaper; 2012; p. 74.

Ferrão RG, Fonseca AFA, Ferrão MAG, De Muner LH. Café Colilon. 3a. ed. Vitória, ES: Incaper; 2019; p. 974.

Ferrão RG, Fornazier MJ, Ferrão MAG, Prezotti LC, Fonseca AFA, Alixandre FT, et al. Estado da arte da cafeicultura no Espírito Santo. In: Tomaz MA et al. (Eds). Seminário para sustentabilidade da cafeicultura. Alegre, ES: UFES; 2008. p. 29-47.

Ferreira DF. Sisvar: a guide for its bootstrap procedures in multiple comparisons. Ciência e Agrotecnologia. 2014;38(2):109-12. doi: doi. org/10.1590/S1413-70542014000200001

Gomes LC, Cardoso IM, Mendonça ES, Fernandes

Revista Árvore 2020;44:e4421 
RBA, Lopes VS, Oliveira TS. Trees modify the dynamics of soil $\mathrm{CO} 2$ efflux in coffee agroforestry systems. Agricultural and Forest Meteorology. 2016;224:30-39. doi: http://dx.doi.org/10.1016/j. agrformet.2016.05.001

Ghosh S, Wilson B, Ghoshal S, Senapati N, Mandal B. Organic amendments influence soil quality and carbon sequestration in the Indo-Gangetic plains of India. Agriculture, Ecosystem and Environment. 2012;156:134-41. doi: doi.org/10.1016/j. agee.2012.05.009

Hanson PJ, Edwards NT, Garten CT, Andrews JA. Separating root and soil microbial contributions to soil respiration: a review of methods and observations. Biogeochemistry. 2000;48:115-46. doi: https://doi.org/10.1023/A:1006244819642

Jia JX, Ma YC, Xiong ZQ. Net ecosystem carbon budget, net global warming potential and greenhouse gas intensity in intensive vegetable ecosystems in China. Agriculture, Ecosystem and Environment. 2012;150:27-37. doi: https://doi.org/10.1016/j. agee.2012.01.011

Jiang J, Guo S, Zhang Y, Liu Q, Wang R, Wang $Z$, et al. Changes in temperature sensitivity of soil respiration in the phases of a three-year crop rotation system. Soil and Tillage Research. 2015;150:139-46. doi: https://doi.org/10.1016/j.still.2015.02.002

Jose S. Agroforestry for ecosystem services and environmental benefits: an overview. Agroforestry System. 2009;76(1):1-10. doi: https://doi. org/10.1007/s10457-009-9229-7

Katayama A, Kume T, Komatsu H, Ohashi M, Nakagawa M, Yamashita M, et al. Effect of forest structure on the spatial variation in soil respiration in a Bornean tropical rainforest. Agriculture and Forest Meteorology. 2009;149(10):1666-673. doi: https:// doi.org/10.1016/j.agrformet.2009.05.007

Kiehl EJ. Fertilizantes orgânicos. Piracicaba, SP: Editora Agronômica "Ceres"; 1985.ISBN 8531800374

Kist BB, Santos CE, Carvalho C, Treichel M. Anuário brasileiro do café 2017. Gazeta Santa Cruz, Santa Cruz do Sul: Editora Gazeta; 2017. 88 p.

Liu Y, Liu S, Wang J, Zhu X, Zhang Y, Liu X.
Variation in soil respiration under the tree canopy in a temperate mixed forest, central China, under different soil water conditions. Ecological Research. 2013;29(2):133-42. doi: https://doi.org/10.1007/ s11284-013-1110-5

Lopes LCL, Vieira HD, Vieira GHS, Souza EF. Projeto de aplicativo móvel capaz de fornecer informações para o manejo de irrigação do café conilon. Irriga. 2019;24(4): 874-89. doi: http:// dx.doi.org/10.15809/irriga.2019v24n4p874-889

Mehta A, Chavas J-P. Responding to coffee crisis: what can we learn from price dynamics?. Journal of Development Economics. 2008;85(1-2):282-11. doi: doi.org/10.1016/j.jdeveco.2006.07.006

Paudel BR, Udawatta RP, Anderson SH. Agroforestry and grass buffer effects on soil quality parameters for grazed pasture ad row-crop systems. Applied Soil Ecology. 2011;48(2):125-32. doi: https://doi. org/10.1016/j.apsoil.2011.04.004

Paulino GM, Alves BJR, Barroso DG, Urquiaga S, Espíndola JAA. Fixação biológica e transferência de nitrogênio por leguminosas em pomar orgânico de mangueira e gravioleira. Pesquisa Agropecuária Brasileira. 2009;44(12):1598-1607. doi:

https://doi.org/10.1590/S0100-204X2009001200006

Prezotti LC, Gomes JA, Dadalto GG, Oliveira JA. Manual de recomendação de calagem e adubação para o Estado do Espírito Santo. $5^{\mathrm{a}}$ ed. Vitória, ES: SEEA/Incaper/CEDAGRO; 2007. 305 p.

Raich JW, Schlesinger WH. The global carbon dioxide flux in soil respiration and its relationship to vegetation and climate. Tellus B. 1992;44(2):81-99. doi:

https://doi.org/10.1034/j.1600-0889.1992.t01-100001.x

Romero-Alvarado Y, Soto-Pinto L,García-Barrios L, Barrera-Gaytán JF. Coffee yields and soil nutrients under the shades of Inga sp. versus multiple species in Chiapas, Mexico. Agroforestry System. 2002;54(3):215-24. doi: https://doi. org/10.1023/A:1016013730154

Silva IR, Mendonça ES. Matéria orgânica do solo. In: Novais RF, Alvarez VVH, Barros NF, Fontes RL, 
Cantarutti RB, Neves JCL, (Eds.). Fertilidade do solo. Viçosa, MG: Sociedade Brasileira de Ciência do Solo; 2007. p. 275-374. 9788586504082

Smith P, Martino D, Cai Z, Gwary D, Janzen $\mathrm{H}$, Kumar P, et al. Greenhouse gas mitigation in agriculture. Philos Transaction Research Society. 2008;363(1492):789-813. doi: 10.1098/ rstb.2007.2184

Souza JL. Agricultura orgânica: tecnologias para produção de alimentos saudáveis. Vitória, ES: Incaper; 2015. ISBN 9788589274241

Stocker TF, Qin D, Plattner GK, Tignor MMB, Allen SK, Boschung J, et al. IPCC, 2013: climate change 2013: the physical science basis. Contribution of Working Group I to the Fifth Assessment Report of the Intergovernmental Panel on Climate Change. Cambridge, United Kington and New York, NY, USA: Cambridge University Press; 2013. 1535 p. Disponível em: https://doi.org/10.1017/ CBO9781107415324
Tedesco MJ, Gianello C, Bissani CA, Bohnen H, Volkweiss SJ. Análise de solo, plantas e outros materiais, $2^{\mathrm{a}}$. ed. Porto Alegre: Universidade Federal do Rio Grande do Sul; (Boletim Técnico 5);1995.

Thomazini A, Mendonça ES, Souza JL, Cardoso IM, Garbin ML. Impact of organic no-till vegetables systems on soil organic matter in the Atlantic Forest biome. Scientia Horticulturae. 2015;182:145-55. doi: http://dx.doi.org/10.1016/j.scienta.2014.12.002

Vaast P, Bertrand B, Perriot J-J, Guyot B, Génard M. Fruit thinning and shade improve bean characteristics and beverage quality of coffee (Coffea arabica L.) under optimal conditions. Journal Science of Food and Agriculture. 2006;86(2):197-04. doi:

https://doi.org/10.1002/jsfa.2338

Yeomans JC, Bremner JM. A rapid and precise method for routine determination of organic carbon in soil. Communication of Soil Science and Plant Analyses. 1988;19(13):1467-76. doi: https://doi. org/10.1080/00103628809368027 